\title{
THE FIRST REPORT OF GEOSMIN AND 2-METHYLISOBORNEOL PRODUCER CYANOBACTERIA FROM TURKISH FRESHWATERS
}

\author{
Zuhal TUNÇ*, Reyhan AKÇAALAN, Latife KÖKER, Meriç ALBAY \\ Istanbul University Faculty of Aquatic Sciences, Istanbul, TURKEY
}

Cite this article as:

Tunç Z., Akçaalan R., Köker L. \& Albay M. 2021. The first report of geosmin and 2-Methylisoborneol producer Cyanobacteria from Turkish freshwaters. Trakya Univ J Nat Sci, 22(2): 163-171, DOI: 10.23902/trkjnat.884423

Received: 23 February 2021, Accepted: 16 June 2021, Online First: 02 August 2021, Published: 15 October 2021

Edited by:

Tuğba Ongun Sevindik

*Corresponding Author:

Zuhal Tunc

zuhal.t@istanbul.edu.tr

\section{ORCID iDs of the authors.}

ZT. orcid.org/0000-0002-6560-6789

RA. orcid.org/0000-0002-0756-8972

LK. orcid.org/0000-0002-9134-2801

MA. orcid.org/0000-0001-9726-945X

Key words:

Geosmin

2-Methylisoborneol

Taste and odour

Cyanobacteria

$P C R$

$G C-M S$

\begin{abstract}
Water users consider the safety of water according to its aesthetic properties, primarily taste and odour. Geosmin (GEO) and 2-methylisoborneol (MIB) are the most common taste and odour compounds in freshwaters which cause an earthy and musty odour in water. Since human nose can detect these compounds in concentrations as low as $10 \mathrm{ng} / \mathrm{L}$, it is essential to monitor drinking waters before consumer complaints and to produce a timely solution. Therefore, it is necessary to identify GEO and MIB producers to manage the problem at its source. Cyanobacteria are one of the main producers of these compounds in freshwater ecosystems. In this study, we analyzed 13 samples (9 cyanobacteria cultures from Bafa Lake, Elmalı Dam Lake, İznik Lake, Küçükçekmece Lake, Manyas Lake and Taşkısığı Lake, and 4 environmental water samples from Erfelek and Günpınar Waterfalls and Ömerli Dam Lake) for GEO and MIB production by HS-SPME (Head space-solid phase microextraction) coupled with GC-MS (gas chromatography-mass spectrometry). The presence of Cyanobacteriaspecific $G E O$ and $M I B$ synthase genes were also analyzed by PCR (Polymerase Chain Reaction). Taste and odour production was confirmed in 2 samples by GC-MS while 4 samples yielded positive results by PCR. All positive samples were environmental samples ( 3 samples from waterfalls from Günpınar and Erfelek Waterfalls, 1 sample from Ömerli Dam Lake -a drinking water reservoir) which were dominated by Nostoc Vaucher ex Bornet \& Flahault, Phormidium Kützing ex Gomont and Pseudanabaena Lauterborn. This is the first report of GEO and MIB producing cyanobacteria in Turkish freshwaters by combining microscopy, analytical and molecular techniques.
\end{abstract}

Özet: Su kullanıcıları, suyun güvenli olup olmadıklarına öncelikle onun tat ve kokusu gibi estetik özelliklerine bakarak karar vermektedir. Geosmin (GEO) ve 2-methylisoborneol (MIB), tatlısularda en yaygın olarak görülen tat ve koku bileşikleridir ve suyun toprak ve küf kokmasına neden olurlar. İnsanlar $<10 \mathrm{ng} / \mathrm{L}$ gibi düşük konsantrasyonlarda dahi bu kokulara hassas olmalarından dolayı bu bileşiklerin içme sularında tüketici şikayetleri oluşmadan önce izlenmesi ve sorunun çözülmesi oldukça önemlidir. Bu sebeple, problemin kaynağında çözümlenebilmesi için GEO ve MIB üreticilerinin tespit edilmesi gereklidir. Tatlısu ekosistemlerinde bu bileşiklerin başlıca üreticilerinden biri siyanobakterilerdir (Cyanobacteria). Bu çalışmada 13 örnek (9 siyanobakteri kültürü, Bafa Gölü, Elmalı Baraj Gölü, İznik Gölü, Küçükçekmece Gölü, Manyas Gölü, Taşkısığı Gölü’nden ve 4 çevresel su örneği, Günpınar, Erfelek şelaleleri ve Ömerli Baraj Gölü’nden) GEO ve MIB üretiminin tespiti için HS-SPME (Tepe Boşluğu-Katı Faz Mikro Ekstraksiyon) GC-MS (Gaz Kromatografi-Kütle Spektrometresi) yöntemi kullanılarak analiz edilmiştir. Ayrıca siyanobakterilere özgü $G E O$ ve MIB sentaz genlerinin varlığının tespiti için PZR (Polimeraz Zincir Reaksiyonu) yöntemi kullanılmıştır. İki örnekte GC-MS ile tat ve koku üretimi tespit edilmiş ve 4 örnekte de PZR ile pozitif sonuç alınmıştır. Pozitif sonuç elde edilen örnekler Nostoc Vaucher ex Bornet \& Flahault, Phormidium Kützing ex Gomont ve Pseudanabaena Lauterborn cinslerinin baskın olduğu çevresel örneklerdir ( 3 şelale, 1 içme suyu kaynağı örneği). Bu çalışma Türkiye tatlısularındaki tat ve koku üreticisi siyanobakterilerin mikroskobik, analitik ve moleküler yöntemler birlikte kullanılarak tespit edildiği ilk kayıttır.

\section{Introduction}

Geosmin (GEO) and 2-methylisoborneol (MIB) are the most common biogenic taste and odour compounds in freshwaters and considered as indicators of water quality by consumers (Webber et al. 2015, Pham et al. 2020).
Therefore, some countries set a guideline value as $10 \mathrm{ng} / \mathrm{L}$ in their drinking waters (Wakayama 2003, NHMRC 2011). The distribution of GEO and MIB in freshwaters varies from lakes, rivers and drinking water reservoirs 
with different trophic status (Jüttner \&Watson 2007) and their production have been reported so far from several countries such as Australia, China, Finland, Japan and USA (NHMRC 2011, Suurnäkki et al. 2015, Otten et al. 2016, Zhang et al. 2016). GEO and MIB concentration levels in drinking water sources may increase to 100-200 ng/L which are 10-20 times higher than the threshold value (Brown et al. 2020).

Cyanobacteria are known to be the main producers of these earthy and musty secondary metabolites in water ecosystems (Watson \& Jüttner 2019). GEO and MIB are easily detected by a human in low concentrations $(<10$ $\mathrm{ng} / \mathrm{L}$ ) (Piriou et al. 2009). Although GEO is more common than MIB (Devi et al. 2020), intracellular MIB is less bound to cell and consequently can be released into water easier than GEO (Watson \& Jüttner 2019). In addition, as a response to environmental factors such as light, temperature etc., MIB production mechanism responds faster in hours while GEO production mechanism response can take days (Watson et al. 2016, Watson \& Jüttner 2019). The first challenge for monitoring and treatment studies is the estimation of GEO and MIB production time and concentration levels (Fakığlu et al. 2018). The second challenge is the presence of different producer groups in the same habitat such as Cyanobacteria, Proteobacteria, Actinobacteria and Ascomycota (Mattheis \& Roberts 1992, Dickschat et al. 2005, Cane et al. 2006, Watson et al. 2016). To overcome this problem, PCR-based studies have started to be used since 2008, in combination with chemical analytical methods and microscopic techniques, to detect the cyanobacteria-specific GEO and MIB synthase gene (Giglio et al. 2008, Wang et al. 2011, Wang et al. 2016).

As one of the main producers, Cyanobacteria has a wide range of distribution in different water sources (lakes, reservoirs, rivers and marine environment) in Turkey (Akcaalan et al. 2009, Akcaalan et al. 2014a, Akcaalan et al. 2014b, Koker et al. 2017). Studies on their presence and toxin production have increased in recent years, but there is a limited number of studies on cyanobacteria-associated taste and odour problems (Albay et al. 2009, Demir et al. 2011, Fakığlu et al. 2018). In addition to this, MIB and GEO have been reporting in drinking water quality reports of İstanbul, especially in summer periods which consequently lead to costly water treatment projects based on granular activated carbon (İSKİ 2020). However, there is no report on producers of GEO and MIB in Turkish freshwaters.

In this study, Cyanobacteria from the culture collection which were isolated from different Turkish freshwaters, and environmental samples were screened for their potential to produce GEO and MIB. To manage the GEO and MIB related taste and odour problems in freshwater ecosystems, it is necessary to detect producer organisms and this is the first study to focus on the detection of taste and odour producing Cyanobacteria using both molecular and analytical methods.

\section{Materials and Methods}

\section{Environmental Sample Collection}

Environmental samples were collected from Ömerli Dam Lake and Günpınar Waterfall and Erfelek Waterfall in Turkey (Table 1). Ömerli Dam Lake sample was taken by a phytoplankton net with $20 \mu \mathrm{m}$ pore size from epilimnion and dominant cyanobacterium was identified by microscopy (Komárek \& Anagnostidis 2005, Komárek 2013). Waterfall samples were collected manually to a plastic bottle and were transported to the laboratory in cold chain. $15 \mathrm{ml}$ environmental samples were centrifuged at $10,000 \mathrm{x}$ g for 10 minutes and pellets were stored at $-20^{\circ} \mathrm{C}$ until DNA extraction. $5 \mathrm{ml}$ of the samples were used in cyanobacterial strain isolation which was done under the conditions reported by Rippka et al. (1979). Under light microscopy, a serial water dilution and trial inoculation process was applied with a sterile Pasteur pipette on the center of an agar plate. All strains were maintained under photoautotrophic growth conditions at $25^{\circ} \mathrm{C} .1 \%(\mathrm{w} / \mathrm{v})$ agar including medium BG11 and its variant BG-11 $1^{\text {minus }}$ (BG-11 with the omission of $\mathrm{NaNO}_{3}$ ) were used for strain isolation.

\section{Cyanobacterial Culture Conditions}

Cyanobacteria cultures (different strains from Cylindrospermopsis G.Seenayya \& N.Subba Raju, Dolichospermum (Ralfs ex Bornet \& Flahault) P.Wacklin, L.Hoffmann \& J.Komárek, Microcystis Lemmermann, Nodularia Mertens ex Bornet \& Flahault, and Sphaerospermopsis Mertens ex Bornet \& Flahault genera) were isolated from different freshwater sources and kept in our cyanobacteria culture collection (Table 1). Cultures were maintained according to Rippka et al. (1979) in the same conditions with environmental samples at $25^{\circ} \mathrm{C}$ in $150 \mathrm{ml}$ liquid Medium BG-11. The isolated cyanobacteria species were mainly planktonic and a few of them were benthic species. Oscillatoria sp. UHCC 0332, which is a known GEO and MIB producer (in Suurnäkki et al. 2015 mentioned as Planktothrix sp. 328), was used as a positive control for GEO and MIB PCR reactions. $15 \mathrm{ml}$ culture samples were centrifuged at $10,000 \mathrm{x}$ g for 10 minutes and pellets were stored at $-20^{\circ} \mathrm{C}$ until DNA extraction.

\section{DNA Extraction}

DNA extraction was done according to the modified Xanthogenate DNA extraction method (Tillett \& Neilan 2000). $1 \mathrm{ml}$ of fresh cell lysis solution was added to the pellets which were obtained after centrifugation of $15 \mathrm{ml}$ samples. The mixture was incubated in $70^{\circ} \mathrm{C}$ water bath for 2 hours and vortexed every 30 minutes during the incubation process. Then, the tubes were centrifuged $10,000 \mathrm{x} \mathrm{g}$ at $4^{\circ} \mathrm{C}$ for 10 minutes. Supernatants were transferred into new tubes. Phenol: Chloroform: Isoamyl alcohol solution (25:24:1) was used for nucleic acid extraction. Isopropyl alcohol $(\geq 99 \%)$ and 1:10 volume of 3 M Sodium acetate were used for precipitation. DNA quantity and quality were checked on NanoDrop with 2000/2000c software. 
Table 1. Collection information for environmental and culture samples.

\begin{tabular}{|c|c|c|c|c|c|}
\hline No & Collection Source & $\begin{array}{c}\text { Dominant } \\
\text { Cyanobacterium } \\
\end{array}$ & $\begin{array}{c}\text { Location } \\
\text { (City-Country) } \\
\end{array}$ & Coordinates & Collection Date \\
\hline \multicolumn{6}{|c|}{ Environmental Samples } \\
\hline 1 & Erfelek Waterfall & $\begin{array}{c}\text { Nostoc sp. } \\
\text { Phormidium sp. }\end{array}$ & Sinop-Turkey & $\begin{array}{l}41^{\circ} 50^{\prime} 10^{\prime \prime} \mathrm{N} \\
34^{\circ} 46^{\prime} 44^{\prime \prime} \mathrm{E}\end{array}$ & 2016, September \\
\hline 2 & Günpınar Waterfall & Nostoc sp. & Malatya-Turkey & $\begin{array}{l}38^{\circ} 33^{\prime} 21^{\prime \prime} \mathrm{N} \\
37^{\circ} 25^{\prime} 23^{\prime \prime} \mathrm{E}\end{array}$ & 2016, April \\
\hline 3 & Ömerli Dam Lake & Pseudanabaena sp. & Istanbul-Turkey & $\begin{array}{l}41^{\circ} 3^{\prime} 13^{\prime \prime} \mathrm{N} \\
29^{\circ} 22^{\prime} 50^{\prime \prime} \mathrm{E}\end{array}$ & 2015, July \\
\hline \multicolumn{6}{|c|}{ Culture Samples } \\
\hline 1 & Bafa Lake & $\begin{array}{l}\text { Nodularia spumigena } \\
\text { IFCC-NS09 } \\
\text { Nodularia spumigena } \\
\text { IFCC-NS18 }\end{array}$ & Aydın-Turkey & $\begin{array}{l}37^{\circ} 30^{\prime} 12^{\prime \prime} \mathrm{N} \\
27^{\circ} 26^{\prime} 34^{\prime \prime} \mathrm{E}\end{array}$ & 2011, June \\
\hline 2 & Elmalı Dam Lake & $\begin{array}{l}\text { Microcystis aeruginosa } \\
\text { IFCC-MA23 }\end{array}$ & İstanbul-Turkey & $\begin{array}{l}41^{\circ} 04^{\prime} 39^{\prime \prime} \mathrm{N} \\
29^{\circ} 07^{\prime} 10^{\prime \prime} \mathrm{E}\end{array}$ & 2010, October \\
\hline 3 & Küçükçekmece Lake & $\begin{array}{c}\text { Microcystis aeruginosa } \\
\text { IFCC-MA01 }\end{array}$ & İstanbul-Turkey & $\begin{array}{l}41^{\circ} 00^{\prime} 16^{\prime \prime} \mathrm{N} \\
28^{\circ} 44^{\prime} 46^{\prime \prime} \mathrm{E}\end{array}$ & 2005, January \\
\hline 4 & İznik Lake & $\begin{array}{c}\text { Dolichospermum mendotae } \\
\text { IFCC-AM02 } \\
\text { Sphaerospermopsis } \\
\text { aphanizomenoides IFCC- } \\
\text { AA02 }\end{array}$ & Bursa-Turkey & $\begin{array}{l}40^{\circ} 26^{\prime} 48^{\prime \prime} \mathrm{N} \\
29^{\circ} 32^{\prime} 02^{\prime \prime} \mathrm{E}\end{array}$ & 2004, August \\
\hline 5 & Manyas Lake & $\begin{array}{c}\text { Microcystis aeruginosa } \\
\text { IFCC-MA28 } \\
\text { Cylindrospermopsis } \\
\text { raciborskii IFCC-CR01 }\end{array}$ & Balıkesir-Turkey & $\begin{array}{l}40^{\circ} 12^{\prime} 08^{\prime \prime} \mathrm{N} \\
27^{\circ} 57^{\prime} 47^{\prime \prime} \mathrm{E}\end{array}$ & $\begin{array}{l}\text { 2010, October } \\
\text { 2005, November }\end{array}$ \\
\hline 6 & Taşkısığı Lake & $\begin{array}{l}\text { Microcystis wesenbergii } \\
\text { IFCC-MW01 }\end{array}$ & Sakarya-Turkey & $\begin{array}{l}40^{\circ} 52^{\prime} 16^{\prime \prime} \mathrm{N} \\
30^{\circ} 24^{\prime} 05^{\prime \prime} \mathrm{E}\end{array}$ & 2005, February \\
\hline
\end{tabular}

Table 2. PCR reaction conditions.

\begin{tabular}{lccccc}
\hline \hline PCR Type & 16S & \multicolumn{2}{c}{ GEO } & \multicolumn{2}{c}{ MIB } \\
\hline \hline Primer Set & $27 \mathrm{~F} /$ & geo78F/ & $288 \mathrm{AF} /$ & MIB3324F/ & $\mathrm{MIB-Rf} /$ \\
& $809 \mathrm{R}$ & geo982R & $288 \mathrm{AR}$ & $\mathrm{MIB} 4050 \mathrm{R}$ & $\mathrm{MIB} \mathrm{Rr}$ \\
Pre-denaturation & $94^{\circ} \mathrm{C}, 5 \mathrm{~min}$. & $94^{\circ} \mathrm{C}, 2 \mathrm{~min}$. & $95^{\circ} \mathrm{C}, 5 \mathrm{~min}$. & $94^{\circ} \mathrm{C}, 2 \mathrm{~min}$. & $94^{\circ} \mathrm{C}, 3 \mathrm{~min}$. \\
Denaturation & $94^{\circ} \mathrm{C}, 20 \mathrm{sec}$. & $94^{\circ} \mathrm{C}, 30 \mathrm{sec}$. & $95^{\circ} \mathrm{C}, 30 \mathrm{sec}$. & $94^{\circ} \mathrm{C}, 30 \mathrm{sec}$. & $94^{\circ} \mathrm{C}, 30 \mathrm{sec}$. \\
Annealing & $55^{\circ} \mathrm{C}, 30 \mathrm{sec}$. & $55^{\circ} \mathrm{C}, 30 \mathrm{sec}$. & $55^{\circ} \mathrm{C}, 30 \mathrm{sec}$. & $59^{\circ} \mathrm{C}, 30 \mathrm{sec}$. & $58^{\circ} \mathrm{C}, 30 \mathrm{sec}$ \\
Elongation & $72^{\circ} \mathrm{C}, 60 \mathrm{sec}$. & $72^{\circ} \mathrm{C}, 60 \mathrm{sec}$. & $72^{\circ} \mathrm{C}, 120 \mathrm{sec}$. & $72^{\circ} \mathrm{C}, 60 \mathrm{sec}$. & $72^{\circ} \mathrm{C}, 60 \mathrm{sec}$. \\
Cycle & 30 & 30 & 55 & 30 & 35 \\
Final elongation & $72^{\circ} \mathrm{C}, 7 \mathrm{~min}$. & $72^{\circ} \mathrm{C}, 5 \mathrm{~min}$. & $72^{\circ} \mathrm{C}, 10 \mathrm{~min}$. & $72^{\circ} \mathrm{C}, 5 \mathrm{~min}$. & - \\
\hline \hline
\end{tabular}

\section{$\underline{P C R}$}

PCR experiments were done according to the published information of the primer sets (Saker et al. 2005, Giglio et al. 2008, Suurnäkki et al. 2015, Wang et al. 2016) with minor modifications (Table 2) after optimization experiments. Cyanobacteria phylum specific 16S PCR reactions were done for all samples. Different cyanobacteria-specific GEO and MIB primer pairs were tested and PCR conditions were optimized with the positive control (Oscillatoria sp. UHCC 0332) DNA. Sterile water with no template DNA was used as the negative control. GEO and MIB PCR reactions were done under mentioned (Table 3 ) conditions with $16 \mathrm{~S}$ positive environmental and culture samples. $20 \mu \mathrm{l} \mathrm{PCR} \mathrm{mixture}$ was prepared which includes $2 \mu \mathrm{l}$ (1-50 ng final) template DNA, 1 U Taq polymerase enzyme (Thermo Fisher) and $0.2 \mu \mathrm{M}$ forward and reverse primers, $0.1 \mathrm{mM}-0.2 \mathrm{mM}$ dNTP mix, $2.5 \mathrm{mM} \mathrm{MgCl}_{2}$, 1x Taq polymerase buffer solution in final concentration with sterile distilled water. PCR products were screened with agarose gel electrophoresis (1.2\%) under $60-90$ volt for $30-80 \mathrm{~min}$ depending on the gel size. 
Table 3. Primers used.

\begin{tabular}{|c|c|c|c|c|}
\hline Primer & Sequences & Amplicon size & Gene & References \\
\hline $\begin{array}{l}27 \mathrm{~F} \\
809 \mathrm{R}\end{array}$ & $\begin{array}{l}\text { 5'-AGAGTTTGATCCTGGCTCAG-3' } \\
\text { 5'-GCTTCGGCACGGCTCGGGTCGATA-3' }\end{array}$ & 782 bp & $16 S r R N A$ & Saker et al. 2005 \\
\hline $\begin{array}{l}\text { geo78F } \\
\text { geo982R }\end{array}$ & $\begin{array}{l}\text { 5'-GCATTCCAAAGCCTGGGCTTA-3' } \\
\text { 5'-ATCGCATGTGCCACTCGTGAC-3' }\end{array}$ & 905 bp & $\begin{array}{c}\text { GEO } \\
\text { Synthase }\end{array}$ & Suurnäkki et al. 2015 \\
\hline $\begin{array}{l}288 \mathrm{AF} \\
288 \mathrm{AR}\end{array}$ & $\begin{array}{l}\text { 5'-AACGACCTGTTCTCCTA-3' } \\
\text { 5'-GCTCGATCTCATGTGCC-3' }\end{array}$ & 288 bp & $\begin{array}{c}\text { GEO } \\
\text { Synthase }\end{array}$ & Giglio et al. 2008 \\
\hline $\begin{array}{l}\text { MIB3324F } \\
\text { MIB4050R }\end{array}$ & $\begin{array}{l}\text { 5'-CATTACCGAGCGATTCAACGAGC-3' } \\
\text { 5'-CCGCAATCTGTAGCACCATGTTGA-3' }\end{array}$ & 726 bp & $\begin{array}{c}\text { MIB } \\
\text { Synthase }\end{array}$ & Suurnäkki et al. 2015 \\
\hline $\begin{array}{l}\text { MIB-Rf } \\
\text { MIB-Rr }\end{array}$ & $\begin{array}{c}\text { 5'-CGACAGCTTCTACAYCYCCATGAC-3' } \\
\text { 5'-CGCCGCAATCTGTAGCACCAT-3' }\end{array}$ & 202 bp & $\begin{array}{l}\text { MIB } \\
\text { Synthase }\end{array}$ & Wang et al. 2016 \\
\hline
\end{tabular}

\section{$\underline{\text { Sequence Analysis }}$}

Sequence analysis was performed for positive GEO and MIB PCR products which were sequenced by 2direction Sanger sequencing technique of MedSanTek (Turkey). Sequences were deposited in GenBank with Accession numbers between MK124613 - MK124616. BLASTn (Basic Local Alignment Search Tool) was used to determine the most similar cyanobacteria-specific GEO and MIB synthase nucleotide sequences to our PCR products (Altschul et al. 1990).

\section{HS-SPME Coupled GC-MS}

GEO and MIB quantification methods were applied with GEO (Dr. Ehrenstorfer XA14005000ME) and MIB commercial standards (Dr. Ehrenstorfer XA15088400ME). Analysis was done in GC (Perkin Elmer Clarus 680) - MS (Clarus SQ 8T) equipped with a column of Elite-5ms using TurboMass software according to the method published by Kaloudis et al. (2017). $10 \mathrm{ml}$ samples were taken from $3^{\text {rd }}$ week old cultures and stored in a freezer $\left(-80^{\circ} \mathrm{C}\right)$ until extraction. Günpınar Waterfall and Ömerli Dam Lake water samples were also stored at $-80^{\circ} \mathrm{C}$. To perform HS-SPME extraction, $10 \mathrm{ml}$ samples were transferred to $20 \mathrm{ml}$ vials which included $3.5 \mathrm{gr} \mathrm{NaCl}$ (Merck 1.06404.1000 99) and closed with a crimper. Extraction was done at $500 \mathrm{rpm}, 55^{\circ} \mathrm{C}$ for 30 minutes with SPME fiber (Supelco 57348-U). After the extraction, the manual injection was performed at $250^{\circ} \mathrm{C}$ for 15 minutes. $\mathrm{GC}$ oven temperature initiation was $60^{\circ} \mathrm{C}$ and it reached $260^{\circ} \mathrm{C}\left(15^{\circ} \mathrm{C} / \mathrm{min}\right)$. Helium was used as mobile phase $(1$ $\mathrm{ml} / \mathrm{min}$ ). Quantification was done in Selected Ion Recording (SIR) mode specific for GEO and MIB.

\section{Results}

To screen presence or potential GEO and MIB-based taste and odour problems and also to detect taste and odour producer Cyanobacteria species in different type of samples (monoalgal culture samples, drinking water reservoir sample and waterfall samples) was aimed in the present study. MIB-based taste and odour problem was found in Ömerli Dam Lake while GEO production was found in Günpınar Waterfall together with a potential of Erfelek Waterfall. Pseudanabaena sp., Nostoc sp. and Phormidium sp. were the dominant Cyanobacteria species in environmental samples (Fig. 1). Oscillatoria sp. UHCC 0332 (Fig. 1a) is a known GEO and MIB producer cyanobacterium and it was used as the positive control sample in PCR and GC-MS analysis.

Cyanobacteria specific GEO and MIB synthase genes were selected for PCR analysis to detect the potential GEO and MIB producer cyanobacteria in the samples. Sequence analysis of PCR products was performed to find the closest nucleotide homologs of our products. To reveal whether taste and odour compounds were synthesized or not, GC-MS analysis was performed. The summary of the results is given in Table 4.

\section{PCR Amplification of GEO and MIB Synthase Genes}

Primarily, the presence of cyanobacteria in environmental samples were determined. Cyanobacteria specific 16S rRNA PCR was conducted and 16S rRNA positive DNA samples with 782 bp PCR product were used in further GEO and MIB specific PCR analysis (Fig. 2).

MIB and GEO PCR optimization studies were done under different annealing temperatures. Relatively shorter target region-specific primers were also tested in the samples. Target regions were successfully amplified in environmental samples. GEO synthase gene was detected in Erfelek and Günpınar Waterfall samples, MIB synthase gene was detected in Ömerli Dam Lake sample and culture samples were negative for both GEO and MIB PCR (Table 4)

\section{Sequence Analysis Results}

The resulting PCR products were Sanger sequenced and aligned by BLAST. The closest homolog of GEO amplicon from Günpınar Waterfall sample (Sequence ID: MK124615) was Nostoc sp. C057 GEO synthase (Sequence ID: CP040281) with a good similarity percentage of $91 \%$. Two different GEO amplicons were sequenced from Erfelek Waterfall sample (Sequence ID: MK124614 and Sequence ID: MK124616). The closest homologs of our sequences were Nostoc sp. C057 GEO synthase (Sequence ID: CP040281) with similarity percentage $85.96 \%$ and Oscillatoria sp. 372/2 GEO 
synthase (Sequence ID: KJ658373) with similarity percentage $93.17 \%$. The closest homolog of MIB amplicon from Ömerli Dam Lake (Sequence ID: MK124613) was Pseudanabaena limnetica str. Castaic Lake MIB synthase (Sequence ID: HQ630883.1) with a perfect similarity percentage of $99 \%$.

\section{$\underline{G C-M S}$}

Quantification of GEO and MIB by HS-SPME Coupled

GEO and MIB commercial standards were prepared and injected in Total Ion Chromatogram (TIC) mode of the mass spectrum to create a specific GC method (Fig. 3). Retention times were found 8.58 for $\mathrm{MIB}$ and 11.25 for GEO, qualifier ions $\mathrm{m} / \mathrm{z}$ values were 95 and 112 , respectively. Dilution series of these standards were injected after HS-SPME extraction and quantification of these compounds in the samples were done according to the calibration curves of these standards $\left(\mathrm{R}^{2} \geq 0.99\right.$ for each compound).

GEO was detected in Günpınar Waterfall sample while MIB was detected in Ömerli Dam Lake sample (Table 4). GEO production could not be analyzed in Erfelek Waterfall sample because of the unavailability of the strain isolation and limited water sample volume. However, earthy/musty odour was easily confirmed by sensory analysis.

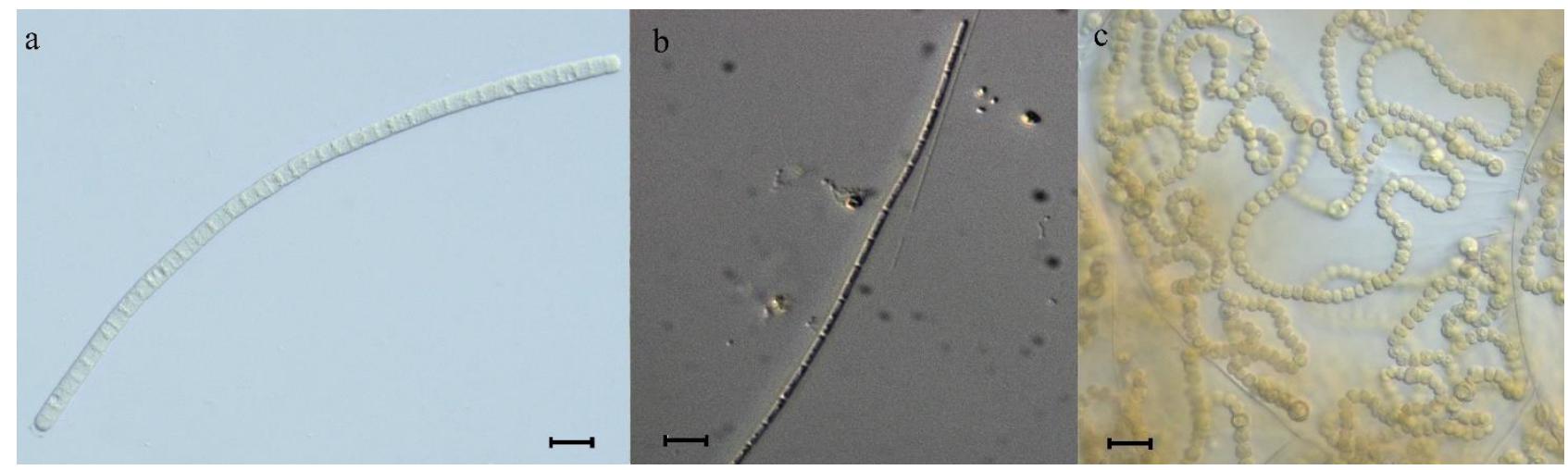

Fig. 1. Microscopy images of potential MIB and GEO producer species detected in the study. a. Oscillatoria sp. UHCC 0332 ; b. Pseudanabaena sp. from Ömerli Dam Lake; c. Nostoc sp. from Günpınar Waterfall. (Scale bar $=20 \mu \mathrm{m})$

Table 4. The species revealed by microscopic observations with their corresponding sources, PCR and GC-MS results and accession numbers from sequencing (nd: not detected, na: not analyzed).

\begin{tabular}{|c|c|c|c|c|c|c|c|}
\hline \multirow[b]{2}{*}{ No } & \multirow[b]{2}{*}{ Source } & \multirow{2}{*}{$\begin{array}{c}\text { Microscopy } \\
\text { Cyanobacterium }\end{array}$} & \multicolumn{2}{|c|}{ PCR } & \multicolumn{2}{|c|}{ GC-MS } & \multirow{2}{*}{$\begin{array}{c}\text { Sequencing } \\
\begin{array}{c}\text { Accession no } \\
\text { (GenBank) }\end{array}\end{array}$} \\
\hline & & & $\begin{array}{c}\text { GEO } \\
(+/-)\end{array}$ & $\begin{array}{l}\text { MIB } \\
(+/-)\end{array}$ & $\begin{array}{c}\text { GEO } \\
(\mathbf{n g} / \mathrm{L})\end{array}$ & $\begin{array}{c}\text { MIB } \\
(\mathbf{n g} / \mathrm{L})\end{array}$ & \\
\hline 1 & Erfelek Waterfall & Nostoc sp. & + & - & na & na & MK124614 \\
\hline 2 & Erfelek Waterfall & Phormidium sp. & + & - & na & na & MK124616 \\
\hline 3 & Günpınar Waterfall & Nostoc sp. & + & - & 323 & nd & MK124615 \\
\hline 4 & Ömerli Dam Lake & Pseudanabaena sp. & - & + & nd & 21 & MK124613 \\
\hline \multicolumn{8}{|c|}{ Culture Samples } \\
\hline 1 & Bafa Lake & $\begin{array}{l}\text { Nodularia spumigena } \\
\text { IFCC-NS09 }\end{array}$ & - & - & nd & nd & - \\
\hline 2 & Bafa Lake & $\begin{array}{l}\text { Nodularia spumigena } \\
\text { IFCC-NS18 }\end{array}$ & - & - & nd & nd & - \\
\hline 3 & Elmalı Dam Lake & $\begin{array}{l}\text { Microcystis aeruginosa } \\
\text { IFCC-MA23 }\end{array}$ & - & - & nd & nd & - \\
\hline 4 & $\begin{array}{l}\text { Küçükçekmece } \\
\text { Lake }\end{array}$ & $\begin{array}{c}\text { Microcystis aeruginosa } \\
\text { IFCC-MA01 }\end{array}$ & - & - & nd & nd & - \\
\hline 5 & İznik Lake & $\begin{array}{l}\text { Dolichospermum mendotae IFCC- } \\
\text { AM02 }\end{array}$ & - & - & nd & nd & - \\
\hline 6 & İznik Lake & $\begin{array}{c}\text { Sphaerospermopsis aphanizomenoides } \\
\text { IFCC-AA02 }\end{array}$ & - & - & nd & nd & - \\
\hline 7 & Manyas Lake & $\begin{array}{c}\text { Microcystis aeruginosa } \\
\text { IFCC-MA28 }\end{array}$ & - & - & nd & nd & - \\
\hline 8 & Manyas Lake & $\begin{array}{c}\text { Cylindrospermopsis raciborskii IFCC- } \\
\text { CR01 }\end{array}$ & - & - & nd & nd & - \\
\hline 9 & Taşkısığı Lake & $\begin{array}{c}\text { Microcystis wesenbergii } \\
\text { IFCC-MW01 }\end{array}$ & - & - & nd & nd & - \\
\hline
\end{tabular}




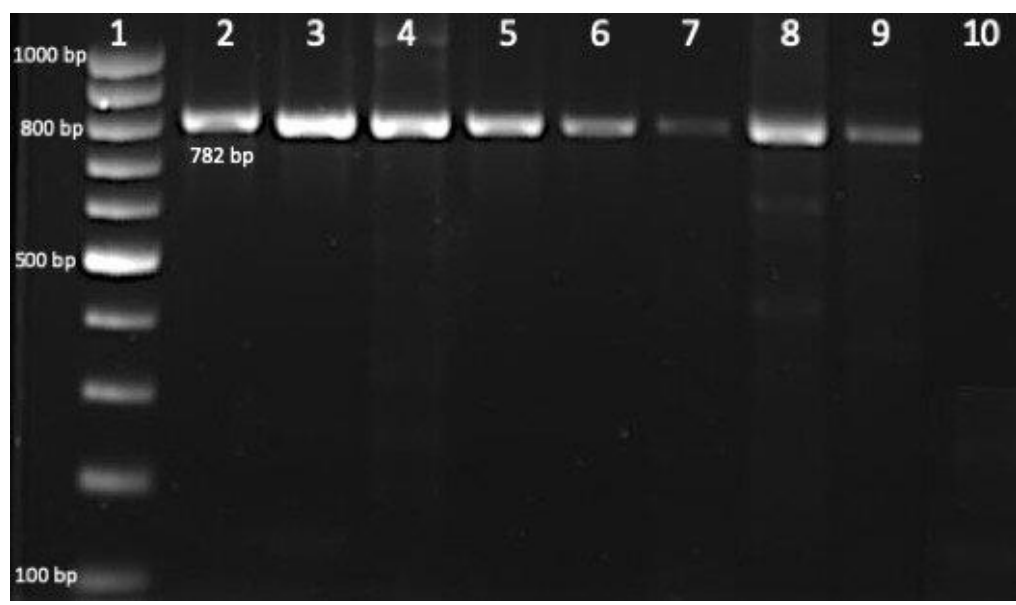

Fig. 2. Cyanobacteria specific 16S rRNA gene amplified from some samples. 1: 100bp size marker (Grisp, Portugal), 2: positive control (UHCC 0332), 3: IFCC-MA01, 4: IFCC-NS18, 5: IFCC-AA02, 6: IFCC-AM02, 7: Günpinar Waterfall, 8-9: Erfelek Waterfall (Phormidium sp. and Nostoc sp. dominant, respectively), 10: negative control.

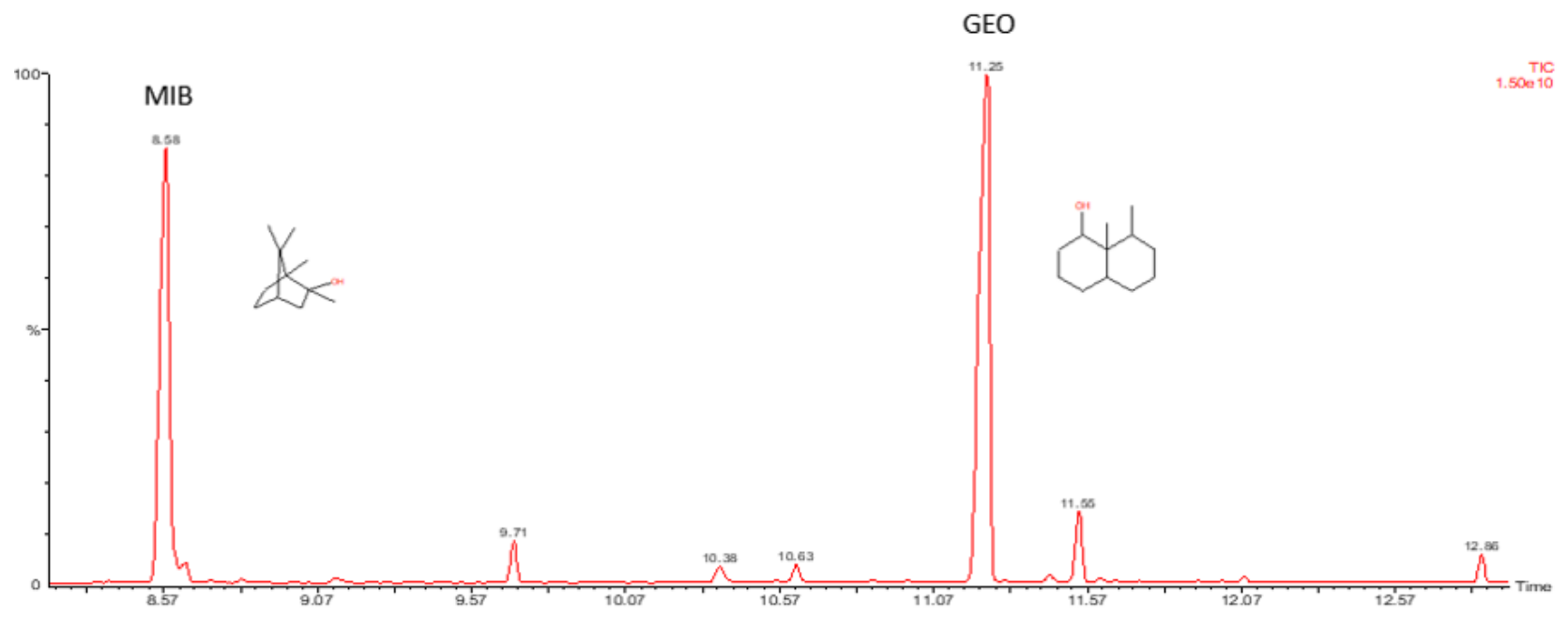

Fig. 3. Total ion chromatogram (TIC) of MIB and GEO mixed standard.

\section{Discussion}

Cyanobacteria are the source of many interesting volatile odour compounds (VOCs) in aquatic environments. Some of these VOCs smell "good" like fruit, violet or magnolia while the rest of them smells "bad" like earth, must, septic, garlic, tobacco, fish or cabbage (Lee et al. 2017). In addition to their odour causing roles in water, these VOCs could serve to enhance the tolerance of producer in harsh conditions, create allelopathic effects on other algae and aquatic macrophytes, and protect the organism against predators (Zuo 2019). GEO and MIB are two VOCs with earthy and musty odour produced by cyanobacteria. They have no known effects on human health, there are limited studies on the role of these compounds in the aquatic environments and the results are contradictory or the effective concentrations $(\mathrm{g} / \mathrm{L})$ are far above common environmental concentrations (Watson 2003). Although their ecological impacts are not yet fully understood, they are the most commonly reported taste and odour compounds in aquatic environments (Devi et al. 2020). The genes which encode the key biosynthetic enzymes which are essential for GEO and MIB production in cyanobacteria have recently been reported (Giglio et al. 2008, Giglio et al. 2011). The nucleotide information is a powerful tool not just to detect GEO and MIB producer Cyanobacteria but also to investigate the effect of environmental parameters on VOCs production at the gene expression level.

In this study, diverse cyanobacteria species in laboratory cultures and environmental samples were screened for the presence of GEO and MIB biosynthetic genes to uncover the responsible producers in aquatic ecosystems. GEO and MIB concentration levels were also quantified to confirm the results of molecular analysis. GEO and MIB biosynthetic genes were successfully amplified in environmental samples. The results were also confirmed with the GC-MS (Table 4). A well-known MIB producer Pseudanabaena sp. was found in an important drinking water reservoir, Ömerli Dam Lake sample (Fig. 1b) and sequence analysis of MIB PCR amplicon from this sample has high similarity with the same genus $M I B$ synthase sequence (99\%). Pseudanabaena species are the 
main reason for MIB episodes in many countries such as China, Japan, South Korea and USA (Izaguirre \& Taylor 1998, Niiyama et al. 2016, Zhang et al. 2016, Chong et al. 2018). However, this is the first MIB producer Cyanobacteria report for Turkey where Pseudanabaena species have a wide distribution in freshwaters including lakes, rivers and thermal waters (Fakıoglu et al. 2011, Taşkın et al. 2019). MIB production level was found relatively high $(21 \mathrm{ng} / \mathrm{L})$ which is above the human odour threshold concentration $(<10 \mathrm{ng} / \mathrm{L})$ and also above the drinking water standard limit levels (10 ng/L) according to Australia and Japan guidelines (Wakayama 2003, NHMRC 2011). In the same operational guideline of Australia, it was suggested to increase the sampling period to every 2 days if $>10 \mathrm{ng} / \mathrm{L}$ GEO/MIB levels are detected at treatment plant inlet and to introduce powdered activated carbon dosing if the same levels are detected at treatment plant outlet. To detect this threshold values is necessary to use appropriate treatment methods in water, and using PCR-based detection tools together with microscopy-based identification would be beneficial to reveal the main sources of the GEO and MIB. MIB producer Pseudoanabaena was detected in one sample from Ömerli Dam Lake. Some other toxic Cyanobacteria species (Aphanizomenon flosaquae Ralfs ex Bornet \& Flahault, Cuspidothrix issatschenkoi (Usachev) P.Rajaniemi, Komárek, R.Willame, P. Hrouzek, K.Kastovská, L.Hoffmann \& K.Sivonen and Microcystis aeruginosa (Kützing) Kützing) were also reported in the lake (Koker et al. 2017). Since the lake has a mesotrophic character, the possibility to have cyanobacteria blooms is possible in the following years with a potential of MIB and cyanotoxin production. Although MIB and other VOCs could not demonstrate the presence of toxic cyanobacteria, nevertheless it could be an early warning system about the problems in an aquatic ecosystem.

Other well-known VOC producers, Nostoc sp. and Phormidium sp., were also identified in Günpınar and Erfelek Waterfall samples (Fig. 1c). Nostoc spp. and Phormidium spp. are common sources of taste and odour problems which were reported in many countries such as Australia, Canada, Finland, Japan, Serbia and USA (Sugiura et al. 1998, Izaguirre \& Taylor 2004, Kutovaya \& Watson 2014, Milovanović et al. 2015, Suurnäkki et al. 2015). Nostoc and Phormidium species were also detected in some important drinking water sources in Turkey (Fakığlu et al. 2011, Koker et al. 2017). Sequence analysis of GEO PCR amplicons from the samples have good similarities with Nostoc sp. and Oscillatoria sp. GEO synthase genes (between 85-93\%). Furthermore, GEO level was found much higher than human threshold limits (321 ng/L) in Nostoc sp. colonies taken from Günpınar Waterfall sample. Unfortunately, due to its limited amount, GC-MS analysis could not be performed in Erfelek samples. The results from Waterfall samples are the first taste and odour reports for these areas and further detailed studies are important to understand the drivers for the proliferation and odour production of these cyanobacteria.
In waterfall samples, $288 \mathrm{AF} / 288 \mathrm{AR}$ primers amplified the targeted region while $78 \mathrm{~F} / 982 \mathrm{R}$ primers did not. The lack of universal GEO synthase primers was considered the main reason for this result. GEO synthase gene sequences were found more diverse to design a universal primer in comparison to $M I B$ synthase region and challenges for $G E O$ primer design has been reported recently (Devi et al. 2020). Therefore, limited sequence data to target a more diverse sequence region may have caused the primer-template DNA mismatches as in previous studies (Kutovaya \& Watson 2014, Otten et al. 2016).

In contrast with the environmental samples, interestingly, isolates of cyanobacteria from Turkish freshwaters are neither capable of producing GEO or MIB nor have a production potential (Table 4). Dolichospermum, Sphaerospermopsis, Cylindrospermopsis and Nodularia were investigated genera in this study which were already reported as GEO or MIB producer in previous studies (Popin et al. 2016, Watson et al. 2016, Zhang et al. 2017, Pham et al. 2020). Also, Microcystis strains were investigated with the knowledge of other coccoid cyanobacteria such as Synechococcus C.Nägeli or Coelosphaerium Nägeli as a producer (Kutovaya \& Watson 2014, Godo et al. 2017). On the other hand, the results are limited with the investigated strains and VOC production may vary from one strain to another (Watson et al. 2016). Further studies should be done also to investigate other VOCs from these genera such as Dimethyl trisulfide (DMTS), $\beta$-Cyclocitral, 2,4,7-Decatrienal, 6-Methyl-5-hepten-2one which cause septic, tobacco, fish or fruit-like odours, respectively, in aquatic environments (Lee 2017).

In this study, GEO positive samples were dominated by benthic filamentous cyanobacteria while MIB positive sample was dominated by planktonic filamentous cyanobacteria. This is the first report of GEO and MIB producing cyanobacteria in Turkish freshwaters which was determined by molecular and analytical methods, identified by microscopy and bioinformatics tools. However, more study should be done for confirmation of gene expression status of these cyanobacteria.

\section{Acknowledgement}

The authors are grateful to Ayça Oğuz (Istanbul University, Turkey) for microscopy images. We thank Cüneyt Nadir Solak (Dumlupınar University, Turkey) and Fatma Çevik (Çukurova University, Turkey) for waterfall samples. We thank Suvi Suurnäkki \& Kaarina Sivonen (Helsinki University, Finland) for their generous gift Oscillatoria sp. UHCC 0332 as a positive control sample for our work. Also, we would like to acknowledge the European Cooperation in Science and Technology, COST Action CA18225 'WaterTOP' for adding value to this study through networking and knowledge sharing with European researchers. 
Ethics Committee Approval: Since the article does not contain any studies with human or animal subject, its approval to the ethics committee was not required.

Author Contributions: Concept: Z.T., R.A., Desing: Z.T., R.A., Execution: Z.T, Material supplying: Z.T., R.A., Data acquisition: Z.T., R.A., Data

\section{References}

1. Akcaalan, R., Köker, L., Gürevin, C. \& Albay, M. 2014a. Planktothrix rubescens: a perennial presence and toxicity in Lake Sapanca. Turkish Journal of Botany, 38(4): 782-789.

2. Akcaalan, R., Köker, L., Oğuz, A., Spoof, L., Meriluoto, J. \& Albay, M. 2014b. First report of cylindrospermopsin production by two cyanobacteria (Dolichospermum mendotae and Chrysosporum ovalisporum) in Lake Iznik, Turkey. Toxins (Basel), 6(11): 3173-3186.

3. Akcaalan, R., Mazur-Marzec, H., Zalewska, A. \& Albay, M. 2009. Phenotypic and toxicological characterization of toxic Nodularia spumigena from a freshwater lake in Turkey. Harmful Algae, 8(2): 273-278.

4. Albay, M., Yüksel, Ş., Özel, A.H., Gürevin, C., Oğuz, B. \& Akçaalan, R. 2009. Environmental factors affecting geosmin and 2-methylisoborneol production in Sapanca Lake, Türkiye. Phycologia, 48: 2.

5. Altschul, S.F., Gish, W., Miller, W., Myers, E. \& Lipman, D. 1990. Basic local alignment search tool. Journal of Molecular Biology, 215(3): 403-410.

6. Brown, J., Nyfennegger, J., Ang, Y., Simpson, M., MacLeod, B., Wolanin, O. \& Gilmore, K. 2020. Biological pretreatment: An innovative approach to addressing taste and odor. AWWA Water Science, 2(2): e1173.

7. Cane, D.E., He, X., Kobayashi, S., Omura, S. \& Ikeda, H. 2006. Geosmin biosynthesis in Streptomyces avermitilis molecular cloning, expression and mechanistic study of the germacradienol/geosmin synthase. The Journal of Antibiotics (Tokyo), 59(8): 471-479.

8. Chong, S., Lee, H. \& An, K.G. 2018. Predicting taste and odor compounds in a shallow reservoir using a threedimensional hydrodynamic ecological model. Water, 10(10): 1396.

9. Demir, N., Pulatsu, S., Kirkagac, M.U., Topcu, A., Zencir, O. \& Fakıglu, O. 2011. Phytoplankton composition considering the odor occurrence in the Porsuk River (Eskisehir-Turkey). Asian Journal of Chemistry, 23(1): 247-250.

10. Devi, A., Chiu, Y.T., Hsueh, H.T. \& Lin, T.F. 2020. Quantitative PCR based detection system for cyanobacterial geosmin/2-methylisoborneol (2-MIB) events in drinking water sources: Current status and challenges. Water Research, 188: 116478.

11. Dickschat, J.S., Bode, H.B., Mahmud, T., Müller, R. \& Schulz, S. 2005. A novel type of geosmin biosynthesis in myxobacteria. The Journal of Organic Chemistry, 70(13): 5174-5182.

12. Fakığlu, Ö., Atamanalp, M. \& Demir, N. 2011. Toxic blue-green algae in dam lakes. Ankara University Journal of Environmental Sciences, 3(2): 65-71. analysis/interpretation: Z.T., R.A., L.K., Writing: Z.T., R.A., L.K., M.A., Critical review: R.A., L.K., M.A.

Conflict of Interest: The authors have no conflicts of interest to declare.

Funding: The study was supported by the Research Fund of Istanbul University (Project Number: FYL-201620569).

13. Fakığlu, M., Karpuzcu, M.E. \& Öztürk, İ. 2018. Evaluation of algae related taste and odor problem in drinking water. Pamukkale University Journal of Engineering Sciences, 24(6): 1141-1156.

14. Giglio, S., Jiang, J., Saint, C.P., Cane, D. \& Monis, P.T. 2008. Isolation and characterization of the gene associated with geosmin production in cyanobacteria. Environmental Science \& Technology, 42(21): 8027-8032.

15. Giglio, S., Saint, C.P. \& Monis, P.T. 2011. Expression of the geosmin synthase gene in the cyanobacterium Anabaena circinalis AWQC318. Journal of Phycology, 47(6): 1338-1343.

16. Godo, T., Saki, Y., Nojiri, Y., Tsujitani, M., Sugahara, S., Hayashi, S., Kamiya, H., Ohtani, S. \& Seike, Y. 2017. Geosmin-producing species of Coelosphaerium (Synechococcales, Cyanobacteria) in Lake Shinji, Japan. Scientific Reports, 7(1): 1-10.

17. İSKİ (İstanbul Water and Sewerage Administration) 2020. Istanbul Water Quality Reports http://www.iski.gov.tr/ (Date accessed: 10.08.2020).

18. Izaguirre, G. \& Taylor, W.D. 1998. A Pseudanabaena species from Castaic Lake, California, that produces 2methylisoborneol. Water Research, 32(5): 1673-1677.

19. Izaguirre, G. \& Taylor W.D. 2004. A guide to geosmin- and mib-producing cyanobacteria in the United States. Water Science \& Technology, 49(9): 19-24.

20. Jüttner, F. \& Watson, S.B. 2007. Biochemical and ecological control of geosmin and 2-methylisoborneol in source waters. Applied and Environmental Microbiology, 73(14): 4395-4406.

21. Kaloudis, T., Triantis, T.M. \& Hiskia, A. 2017. Determination of geosmin and 2-methylisoborneol in water by HS-SPME-GC/MS, 469-474. In: Meriluoto, J., Spoof, L \& Codd, G.A. (eds). Handbook of Cyanobacterial Monitoring and Cyanotoxin Analysis. John Wiley \& Sons, Chichester, $576 \mathrm{pp}$

22. Koker, L., Akcaalan, R., Oguz, A., Gaygusuz, O., Gurevin, C., Akat Kose, C., Gucver, S., Karaaslan, Y., Erturk, A., Albay, M. \& Kinaci, C. 2017. Distribution of toxic cyanobacteria and cyanotoxins in Turkish waterbodies. Journal of Environmental Protection and Ecology, 18(2): 425-432.

23. Komárek, J. 2013. Cyanoprokaryota: 3rd Part Heterocytous Genera. Springer-Verlag, Berlin/Heidelberg, $1130 \mathrm{pp}$.

24. Komárek, J. \& Anagnostidis, K. 2005. Cyanoprokaryota: 2nd Part Oscillatoriales. Elsevier Spektrum Akademischer Verlag, München, 759 pp. 
25. Kutovaya, O.A. \& Watson, S.B. 2014. Development and application of a molecular assay to detect and monitor geosmin-producing cyanobacteria and actinomycetes in the Great Lakes. Journal of Great Lakes Research, 40(2): 404414.

26. Lee, J., Rai, P.K., Jeon, Y.J., Kim, K.H. \& Kwon, E.E. 2017. The role of algae and cyanobacteria in the production and release of odorants in water. Environmental Pollution, 227: 252-262.

27. Mattheis, J.P. \& Roberts, R.G. 1992. Identification of geosmin as a volatile metabolite of Penicillium expansum. Applied and Environmental Microbiology, 58(9): 3170-3172.

28. Milovanović, I., Mišan, A., Simeunović, J., Kovač, D., Jambrec, D. \& Mandić, A. 2015. Determination of volatile organic compounds in selected strains of cyanobacteria. Journal of Chemistry, 2015. http://dx.doi.org/10.1155/2015/969542

29. NHMRC, NRMMC 2011. Australian Drinking Water Guidelines. National Water Quality Management Strategy. National Health and Medical Research Council, National Resource Management Ministerial Council, Commonwealth of Australia, Canberra. https://www.nhmrc.gov.au/file/16934/download?token=g AKh3uQk (Date accessed: 12.12.2020).

30. Niiyama, Y., Tuji, A., Takemoto, K. \& Ichise, S. 2016. Pseudanabaena foetida sp. nov. and $P$. subfoetida sp. nov. (Cyanophyta/Cyanobacteria) producing 2methylisoborneol from Japan. Fottea Olomouc, 16(1):1-11.

31. Otten, T.G., Graham, J.L., Harris, T.D. \& Dreher, T.W. 2016. Elucidation of taste-and odor-producing bacteria and toxigenic cyanobacteria in a midwestern drinking water supply reservoir by shotgun metagenomic analysis. Applied and Environmental Microbiology, 82(17): 5410-5420.

32. Pham, T. L., Bui, M.H., Driscoll, M., Shimizu, K., \& Motoo, U. 2020. First report of geosmin and 2methylisoborneol (2-MIB) in Dolichospermum and Oscillatoria from Vietnam. Limnology, 22(1): 43-56.

33. Piriou, P., Devesa, R., De Lalande, M. \& Glucina, K. 2009. European reassessment of MIB and geosmin perception in drinking water. Journal of Water Supply: Research and Technology-AQUA, 58(8), 532-538.

34. Popin, R.V., Rigonato,. J, Abreu, V.A.C., Andreote, A.P.D., Silveira, S.B., Odebrecht, C. \& Fiore, M.F. 2016. Draft genome assembly of the bloom-forming cyanobacterium Nodularia spumigena strain CENA596 in shrimp production ponds. Genome Announcements, 4(3): e00466-16.

35. Rippka, R., Deruelles, J., Waterbury, J.B., Herdman, M. \& Stanier, R.Y. 1979. Generic assignments, strain histories and properties of pure cultures of cyanobacteria. The Journal of General Microbiology, 111(1): 1-61.

36. Saker, M.L., Jungblut, A.-D., Neilan, B.A., Rawn, D.F.K. \& Vasconcelos, V.M. 2005. Detection of microcystin synthetase genes in health food supplements containing the freshwater cyanobacterium Aphanizomenon flos-aquae. Toxicon, 46(5): 555-562.

37. Sugiura, N., Iwami, N. \& Inamori, Y. 1998. Significance of attached cyanobacteria relevant to the occurrence of musty odor in Lake Kasumigaura. Water Research, 32(12): 35493554.
38. Suurnäkki, S., Gomez-Saez, G.V., Rantala-Ylinen, A., Jokela, J., Fewer, D. \& Sivonen, K. 2015. Identification of geosmin and 2-methylisoborneol in cyanobacteria and molecular detection methods for the producers of these compounds. Water Research, 68: 56-66.

39. Taşkın E., Akbulut A., Yııldı A., Şahin B., Şen B., Uzunöz C., Solak C.N., Başdemir D., Çevik F., Sönmez F., Açikgöz İ., Pabuçcu K., Öztürk M., Alp M.T., Albay M., Çakır M., Özbay Ö., Can Ö., Akçaalan Albay R., Atıcı T., Koray T., Özer T., Karan T., Aktan Turan Y. \& Tunç Zengin Z. 2019. A Checklist Of The Flora Of Turkey (Algae). Ali Nihat Gökyiğit Vakfi, İstanbul, 804 pp.

40. Tillett, D. \& Neilan, B.A. 2000. Xanthogenate nucleic acid 1solation from cultured and environmental cyanobacteria. Journal of Phycology, 36(1): 251-258.

41. Wakayama, H. 2003. Revision of Drinking Water Quality Standards in Japan, Ministry of Health Labour and Welfare, Japan.

http://www.nilim.go.jp/lab/bcg/siryou/tnn/tnn0264pdf/ks0 264011.pdf (Date accessed: 12.12.2020).

42. Wang, Z., Xu, Y., Shao, J., Wang, J. \& Li, R. 2011. Genes associated with 2-methylisoborneol biosynthesis in cyanobacteria: isolation, characterization, and expression in response to light. PLoS One, 6(4): e18665.

43. Wang, Z., Song, G., Shao, J., Tan, W., Li, Y. \& Li, R. 2016. Establishment and field applications of real-time PCR methods for the quantification of potential mib-producing cyanobacteria in aquatic systems. Journal of Applied Phycology, 28: 325-333.

44. Watson, S.B. 2003. Cyanobacterial and eukaryotic algal odour compounds: signals or by-products? A review of their biological activity. Phycologia, 42(4): 332-350.

45. Watson, S.B., Monis, P., Baker, P. \& Giglio, S. 2016. Biochemistry and genetics of taste- and odor-producing cyanobacteria. Harmful Algae, 54: 112-127.

46. Watson, S.B. \& Jüttner, F. 2019. Biological production of taste and odour compounds, taste and odour in source and drinking water: causes, controls, and consequences, 63112. In: Lin, T.F., Watson, S., Dietrich, A.M. \& Suffet, I.H. (eds). Taste and Odour In Source and Drinking Water: Causes, Controls, and Consequences. IWA Publishing, London, $322 \mathrm{pp}$.

47. Webber, M.A., Atherton, P. \& Newcombe, G. 2015. Taste and odour and public perceptions: what do our customers really think about their drinking water? Journal of Water Supply: Research and Technology-Aqua, 64(7): 802-811.

48. Zhang, T., Zheng, L., Li, L. \& Song, L. 2016. 2methylisoborneol production characteristics of Pseudanabaena sp. FACHB 1277 isolated from Xionghe Reservoir, China. Journal of Applied Phycology, 28: 33533362.

49. Zhang, J., Li, L., Qiu, L., Wang, X., Meng, X., You, Y., $\mathrm{Yu}$, J. \& Ma, W. 2017. Effects of climate change on 2methylisoborneol production in two cyanobacterial species. Water, 9(11): 859.

50. Zuo, Z. 2019. Why algae release volatile organic compounds-the emission and roles. Frontiers in Microbiology, 10: 491. 